Document downloaded from:

http://hdl.handle.net/10251/62643

This paper must be cited as:

Moreno Pérez, OM. (2015). The Morphology of Multiple Household Family Farms.

Sociologia Ruralis. 55(2):125-149. doi:10.1111/soru.12062.

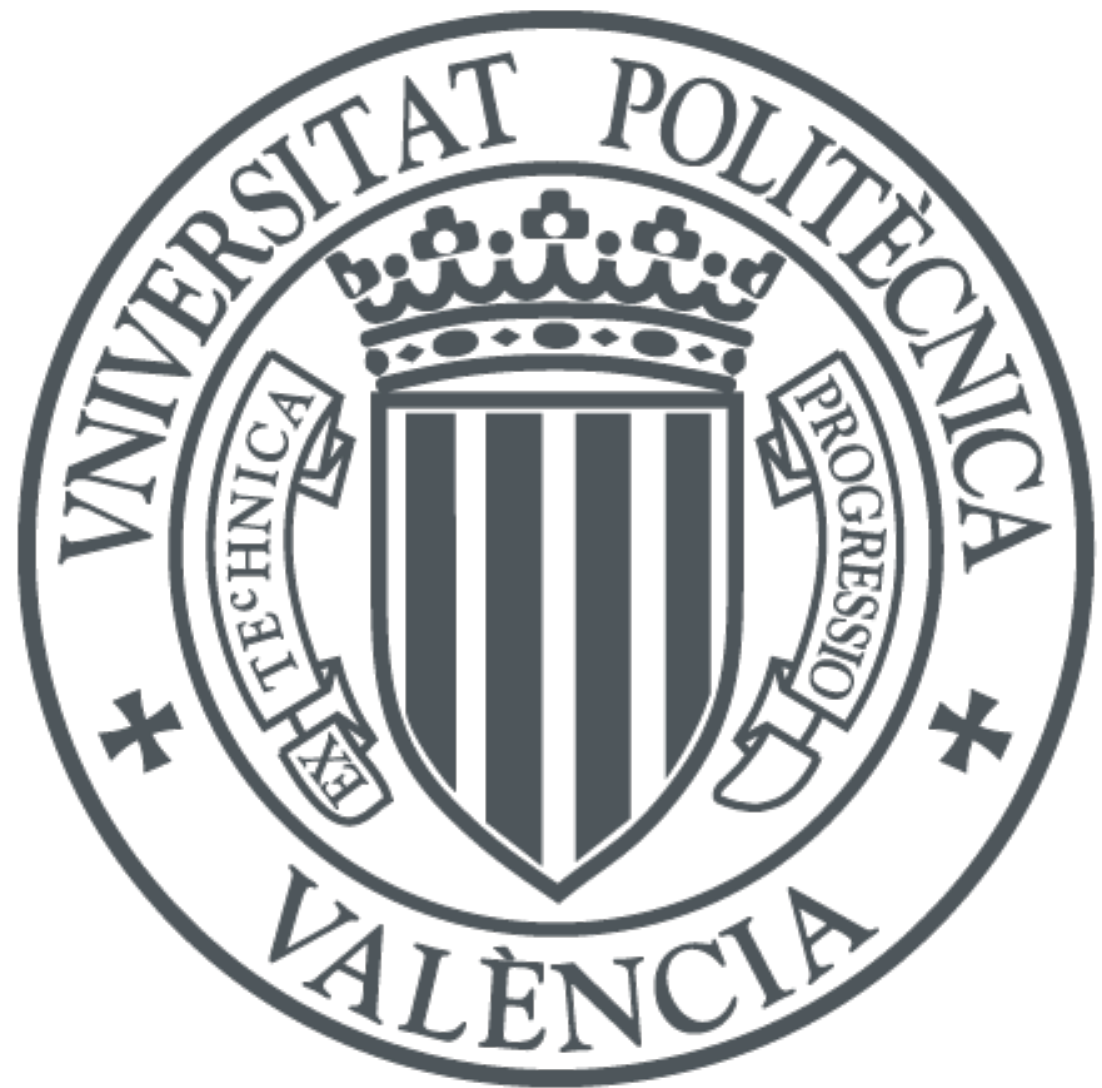

The final publication is available at

http://dx.doi.org/10.1111/soru.12062

Copyright Wiley: 24 months; Wiley

Additional Information

This is the peer reviewed version of the following article: Moreno-Pérez, O. M. and Lobley, M. (2015), The Morphology of Multiple Household Family Farms. Sociologia Ruralis, 55: 125-149, which has been published in final form at http://dx.doi.org/10.1111/soru.12062. This article may be used for non-commercial purposes in accordance with Wiley Terms and Conditions for Self-Archiving. 


\section{The Morphology of Multiple Household Family Farms}

\section{Introduction}

The vast majority of farms in the world are still family-based, despite the context of globalisation and competitive pressure in which agriculture evolves. This predominance is also overwhelming in developed countries: holdings classified as family farms by the US Department of Agriculture represent 98 per cent of the total in that country (Hoppe and Banker, 2010); in the European Union (where agricultural statistics do not include an operational definition of the family farm) farm structures data showed that 98 per cent of farms were held by a 'natural person' (European Commission, 2012) ${ }^{1}$. Similarly, corporate holdings only represent 1.5 per cent of all farms in Australia (Clark, 2008). It is thus widely accepted that family farms, far from being displaced by agribusiness, have managed to resist globalising tendencies and even consolidate whilst submitted to market forces (Raymond, 2013).

The nature and condition of the plethora of holdings generally labeled as 'family farms' is neither homogeneous nor static. Agricultural statistics show a sustained, even dramatic drop in the number of holdings in Western countries over the last decades (Hill, 2006), in parallel to the concentration of agricultural employment, turnover and land in a 'hard core' of large-scale holdings, among which "family-based" forms of production are also predominant (Hoppe et al., 2008; Magnan, 2012).

However, aggregate data on farm structures obscures an important process of differentiation at the farm level (Arnalte-Alegre, 2014). The investigation of the individual responses of farm families to the challenges of their surrounding environment has drawn considerable attention from analysts (Johnsen, 2004; Lobley and Potter, 2004). Farm strategies have been examined as a combination of an array of choices (Evans, 2009) involving the redeployment of familyfarm resources as well as changes in disparate facets of business management. Some of these adaptation patterns have allowed certain family-based holdings to expand their operations and reach the upper scales of size; in this vein, scholars have emphasised the adoption of labour-saving technology (Schmitt, 1991; Moreno-Pérez and Ortiz-Miranda, 2008) and the increasing use of hired, non-family labour and rented land as growth strategies on family farms (Arnalte-Alegre, 2002).

In contrast, much less attention has been paid to the issue that concerns us here; family household processes and organisational changes as elements of micro level differentiation of the farm businesses. More specifically, we focus on the configuration of technical-economic units jointly operated by several households.

Recent evidence points to the growth of these organisational forms in developed countries, although there is little information from official statistics on this issue. Lillywhite and Duffy (2001), for instance, stated that 'multifamily' farms were widespread in lowa and underlined the paucity of research on this type of holdings. When the US Agricultural Census started to collect data on the number of households sharing in the net income of the business in 2002, as many as 21 per cent of holdings were found to be shared by more than one household, a figure unchanged in 2007 (USDA, 2009). In Canada, the proportion was 16 per cent in 2001 (Bollman, 2005). The need to supplant the one-farm-one-household assumption was later highlighted in official reports (eg Allen and Harris, 2005). In Europe, Van der Veen and Van Bommel (2005) and Poppe et al. (2004) drew attention to family partnerships in Belgian and Dutch farming. Johnson et al. (2009), in one of the rare cross-country analyses on this topic ${ }^{2}$, explored the information revealed by the statistics available in USA, Canada, Italy and the 
Netherlands on multiple-owner, multiple-operator or multiple-household farms, and discussed the complex governance structures exhibited by farm businesses in developed countries.

However interesting these contributions are ${ }^{3}$, statistical data clearly do not suffice to capture the morphology and rationale of these holdings: knowledge of this kind requires context and agricultural system specific micro-empirical information.

Consequently this paper focuses on a study area where agriculture has undergone profound transformations over the last few decades, the Spanish county of "Campo the Cartagena" located on the borderline between the Mediterranean provinces of Murcia and Alicante-, where intensive farming has progressed in parallel with a remarkable development of residential tourism. A myriad of small-scale, professionalised farms shape a fairly homogeneous agricultural system specialising in horticulture and, to a lesser extent, citrus fruit production.

In this context, we aim to answer the following research questions: i) To what extent are extended family partnerships widespread in this agricultural system?, ii) In which ways can these governance structures be an element of farm differentiation?, iii) What is the family morphology of these farms and how does it overlap with their legal arrangements?, iv) What is the assembly of multiple household farms in the conventional intergenerational transfer patterns?

It is important to note that a comprehensive sociological analysis of the intra-family relationships in the core of these holdings exceeds the scope of this paper. Nevertheless, this investigation constitutes a valuable step forward insofar as it takes a closer look at a little researched configuration of family farming, contextualises its analysis within the 'family-scape' of a specific area and draws connections informed by a theoretical understanding of family farming.

The remainder of the paper is structured as follows. First we review the theoretical framework of family farming, with an emphasis on work that has explored the boundary between family and corporate farming; in Section 3 the methodological approach of the investigation is presented. The subsequent two sections provide a deeper analysis of the development and specificities of this agricultural system, which are useful to properly frame the farm familyscapes analysed in Section 6. Later we hypothesise on the intergenerational farm transfer trajectories in this area in the light of the extensive literature on farm family succession, and finally we draw conclusions and point at future directions for research.

\section{The scholarly literature on family farming: beyond the traditional agrarian question}

The persistence of family farms in the developed world within a capitalist context aroused considerable interest in scholarly debates on the political economy of agriculture, which were particularly fertile from the 1970s to the mid-1990s. Many of these discussions focused on the predicated decline of family farms - be it by the direct proletarisation of family farmers (following the orthodox Marxist tradition) or by means of indirect submission to capital forces (Davis, 1980; Whatmore et al., 1987) - and the varied forms whereby family farms could resist and even outcompete capitalist holdings (eg Friedmann, 1978). Some authors argued that it was too simplistic to assume a relationship of domination or separation between family and capitalist forms of production, and instead drew attention to the permeability of family farms to external relations, their flexibility and multiple strategies of adaptation to cope with capitalism (Gasson et al. 1988; Marsden et al., 1989; Munton and Marsden, 1991).

In parallel to these discussions, the very concept of the "family farm" was subject to profound debate. Some commentators held that dependency on family labour was a necessary condition of family farming (eg Djurfeldt, 1996; Hill, 1993); others downplayed the importance of this 
issue (Errington, 1996). More multifaceted ideal type conceptualisations of the "family farm business", such as that developed by Gasson and Errington (1993), put the emphasis on family members as farm managers and providers of capital, as well as on the intergenerational transfer of the business. When these defining characteristics are highlighted no minimum proportion of labour supplied by the family is required. Moreover, the traditional identification of family farms with smallholdings is superseded. Family relationships were argued to be, in fact, more central to the operative success of large farms, as they have more capacity to involve several family members and provide a sounder basis for intergenerational continuity ${ }^{4}$. Therefore, rather than redounding in the self-exploitation of family labour as an explanatory factor for family farm survivability, commentators focused on the financial and technical expertise of the family and its ability to control the hired workforce and plan capital investments as key elements of farm differentiation (Hutson, 1987; Marsden et al. 1992).

During these debates some scholars observed the configuration of complex family organisational structures in British farming. Marsden (1984) found that agricultural production in the prosperous farming area of North Humberside was pervaded by tight-knit multistructure farm businesses held by several families with an inter-generational link, and stressed the greater ability of such holdings to expand upon the base of the pooled labour, skills and capital of the extended family. In the same vein, Hutson (1987) held that, in the Welsh county of Pembrokeshire, the ethic of family continuity that was previously achieved through the fragmentation of holdings had been replaced by "a collective ethic of corporate expansion" ( $p$. 227) in large farms jointly held by farm principals and their heirs. For this author, family farms were more successful as management units than as labour units.

However, this particular line of research received little attention in subsequent years. In the second half of the 1990s and the 2000s, much family farming research was subsumed within broader debates associated with the so-called post-productivist transition of agriculture (eg Ilbery and Bowler, 1998), multifunctionality of agriculture (eg Marsden et al. 2002; Van der Ploeg and Roep, 2003) and agricultural restructuring (eg Lobley and Potter, 2004; Johnsen, 2004). Much of this considerable body of work revolved around farm adjustment trajectories disengaging from mainstream agriculture to cope with the agrarian cost-price squeeze notably diversification and pluriactivity (eg McNally, 2001; Chaplin et al. 2004; Meert et al. 2005; Kinsella et al., 2000).

More recently, the focus of post-marxist debates on the political economy of agriculture have substantially moved from micro-level differentiation processes to large scale phenomena such as landgrabbing or global food regimes (Magnan, 2013). Yet, some scholars have continued the long-established lines of research on family farming -see, among others, the worldwide analysis of Brookfield and Parsons (2007), the theoretical reviews by Brookfield (2008) and Calus and van Huylenbroeck (2010) and the farm succession studies contained in Lobley et al. (2012). Importantly for the matter that concerns us here, few contemporary works have paid attention to the changing patterns of family ownership and structure in units at the junction between family and corporate farming.

Prichard et al. (2007) highlight the emergence of organisational forms built around extended family networks in very large, specialised and capital-intensive holdings in Australian processing tomato farming, and coined the term 'farm family entrepreneurs' to encapsulate the situation in which farm families "remain in the economic heart of farm ownership and operation, but in the context where they relate to their land-based assets through legal and financial structures characteristic of the wider economy" (p. 76). Later, Magnan (2012) also used the label 'farm family entrepreneurs' to refer to the vertically integrated mega-farms of the grain sector in Saskatchewan (Canada). These holdings, also arranged as multiplehousehold partnerships, scaled up their operations and exhibit a corporate-style organisation, yet retain some essential features of family forms of production - the families providing labour, 
overall strategic direction and a core land base to the farm. Machum (2005) revealed that the union of kin families helped to explain the success of some family farms in the Atlantic Canadian province of New Brunswick. Critically, from all these authors' view, these farms do not form part of an incomplete transition between the ideal categories of 'family' and 'corporate' farms, but constitute distinct, stable, hybrid social and economic formations in their own right.

Some European authors have recently aligned with this approach. Hervieu and Purseigle (2011, 2013) challenge the longstanding monolithic conceptions of family farming in French political discourse and categorised family farms into different 'models' - some of them close to a corporate rationale. In the region of Camargue, Nguyen and Purseigle (2012) identified a heterogeneous group of "non-standard" holdings - with hybrid traits between a family and a purely business mode of production - and explored their complex connections with 'traditional' family farms. Raymond (2013) interprets the changes in family farming, rather than as corporatisation of agriculture, "as the connection of different processes such as the transformation of family structures, of farmers' lifestyles, of the diversification of production techniques, of forms of partnership and of farm management" (p. 285).

Significantly, Raymond also points to evidence on the configuration of partnerships which are based neither on neighbouring nor on family, but on shared affinities and mutual trust, in Côte d'Or field-crop farms. Within these structures (which frequently have an informal nature) a profound division of labour makes it possible to simplify the workload of each partner. Farming is thus conceived as " $a$ set of practices which can, in part, be separated from one to another, and which farmers are able to recombine in a singular fashion" (p. 292). These work groups enable individual farmers (those who are the sole member of the family involved in the farm) to scale up their operations while they save labour time and maintain their lifestyle.

These examples hint at the importance of multiple-operator and multiple-household farms of different kinds in very diverse social, cultural, economic and farming conditions. The multifaceted nature of these partnerships provides scope to draw interesting connections between the traditional research on family farming and family business studies, a discipline in which an increasing body of literature discusses the distinctive features and possible comparative advantages of family vs corporate firms - see eg Carney (2005), Irava and Moores (2010), Mazzi (2011) and Chrisman et al. (2013).

\section{Approach}

The bulk of the fieldwork underlying this paper was carried out in 2009. It was initiated with three preliminary meetings with i) one technician of the regional agricultural administration; ii) three members of the board of directors of the largest cooperative of the study area and three farmers and iii) two members of the technical staff of a vegetable auction market and two farmers. These meetings provided us with an overall picture of the development of agriculture in Campo de Cartagena since the 1970s and outlined the general traits of farming in this area. Later, 14 in-depth interviews were conducted to specifically deepen our understanding of the technical aspects of this agricultural system and to draw connections between these specificities and family issues such as succession patterns, farm family life cycle and extendedfamily arrangements. Interviews were conducted with eight technicians of cooperatives or vegetable auction markets - selected on the basis of their experience in the field and their close connection with many farmers on the ground -, the leader of the most important farmers' union in the study area (a farmer himself), and five farmers.

These preliminary interviews were used to inform the design of a questionnaire survey of 135 farmers aimed at collecting extensive micro-level information ${ }^{5}$. Respondents were contacted 
on a random basis from the lists of members provided by some co-operatives, and also by directly going to their farms or to vegetable auction markets. Each interview was based on one farm -i.e. a technical-economic unit operating under single management, even if it involved multiple operators or multiple households. In order to ensure that respondents were able to reliably answer the numerous questions about the farm and the (extended) family, they were selected only if they were members of the farm family and involved in strategic farm decisionmaking.

The questionnaire included several sections. In the first a set of questions identified the farm holders ${ }^{6}$ and determined whether or not they live in the same household, their kin relationship and which of them play an important role in decision making. Subsequent sections addressed farm characteristics, the household's composition and other gainful activities ${ }^{7}$, farm labour and disparate aspects of farm management. Finally, semi-structured questions were included to reconstruct the main decisions regarding farm investments taken over the previous 20 years.

The sample was reasonably representative of the farm structures and family-scapes portrayed in the interviews. Thus, the bulk of the survey farms exhibited a greenhouse area which fell in the range identified by informants as the most frequent in the zone (1.5 to $2.5 \mathrm{Ha}$ ), and the proportion of farms with different agricultural orientations (eg citrus vs vegetable-oriented ones) and technological levels (eg type of greenhouse) also matched with interviewees' information.

Finally, a second stage of fieldwork was undertaken in 2012 aimed at completing and updating the earlier information. Another interview with the leader of the farmers' union revealed the main changes undergone by farming in this area in recent times. In addition, our knowledge on the rationale of inter-family arrangements was reinforced with four in-depth interviews with holders of multifamily farms (not included in the original survey). The information obtained with these and the former interviews was also used to hypothesise on the farm succession itineraries from cross-sectional data of the survey.

\section{Agricultural change and family farming in Campo de Cartagena}

Located in a South-facing plain sheltered from the wind, with high temperatures in summer, mild winter, low humidity and excellent luminosity, Campo de Cartagena benefits from exceptional conditions for early-season vegetable growing (Gómez-Espín et al., 2011). However, the extreme aridity of this steppe, with precipitation of barely $300 \mathrm{~mm}$ per year, does not suit crops requiring abundant water. Subsoil water was systematically collected to complement the irregular endowment of the Segura fluvial basin from the 1950s, and promoted a gradual substitution of permanent crops for vegetables (Costa and Canales, 1980). In the subsequent two decades, infrastructure was improved and new technologies of cultivation under plastic, and notably greenhouses, were introduced in the area. The early constructions became widespread by the late 1970s, prompting a spectacular increase in yields and quality, making it possible to take advantage of the expanding European demand for early season vegetables - a replication of the model that succeeded in Almería one decade before (Galdeano-Gómez et al., 2011).

The three adjacent municipalities analysed here (San Javier, San Pedro del Pinatar y El Pilar de la Horadada) pioneered greenhouse expansion in Campo de Cartagena and specialised in green pepper cultivation. Local family farms rapidly adapted to greenhouse production (Morales Gil, 1997); the mobilisation of an abundant and flexible family workforce facilitated making the most of their limited land endowment. In order to ease the connection of smallholders with European distribution channels, cooperatives and other farmers' organisations were created in this "zero zone" over the 1970s and consolidated in the 
following decade -although many farmers continued commercialising their production in traditional auction markets, more oriented to the national urban market.

The real turning point of farm expansion in Campo de Cartagena was the completion of a 300 $\mathrm{km}$-long water transfer between Tajo and Segura river basins in 1979, as a result of a State-led project aimed at increasing the availability of water in the Southeastern Spain and, ultimately, boosting the development of this region. Access to this water triggered an extraordinary expansion of irrigation and gave impetus to agricultural exports, bringing about profound transformations in the landscape and the socioeconomic dynamics of this area. Limits of family labour and the scarcity of hired workers were the main constraint for farm expansion in this period, before the arrival of Maghrebi immigrants to this area in the 1980s, that were extensively occupied in greenhouses ever since (Pedreño, 1999; Arnalte-Alegre and OrtizMiranda, 2013).

Farm growth peaked between mid-1990s and mid-2000s, boosted by the end in 1993 of the transitional period after the Accession of Spain to European Economic Community -which meant the definitive openness of European markets to Spanish agricultural products. The introduction of the 'California' variety of green pepper, greatly appreciated by European consumers, also stimulated exports in this zone. The profits associated with the export market, together with the easy credit conditions prevailing in this period, prompted the capitalisation of farms. Intensification was the preferred pathway of farm growth in a context of high land prices (particularly during the real estate 'bubble' in 1997-2007). Thus, many farms embarked on the building of new greenhouses, the refurbishment of existing ones (Table 1) and the introduction of drip irrigation for open air crops. Compared with these transformations, expansion of the farmed area was relatively infrequent. The cases of land purchase could be mainly aimed at increasing the family patrimony, rather than merely responding to a strategy of expansion of the farm business (Moreno-Pérez et al. 2011).

\section{[Table 1 around here]}

The survey performed in 2009 revealed the structural characteristics of farms in this area in recent times. Mean farm size was 9.5 hectares; a half being below 5 hectares. 90 per cent of farms have at least one greenhouse, typically covering between 1 and 2.5 hectares, although great disparities were found on closer inspection both in terms of size and use of technology (see Moreno-Pérez et al., 2011). Greenhouses were mainly oriented to green pepper growing, although cultivation of cut flowers was found in 16 per cent of farms. In 75 per cent of cases, greenhouses were combined with open-air cultivation of vegetables and/or permanent crops (notably citrus fruits).

Around 10 years ago, the moderation of green pepper prices and the rise in input prices (notably diesel) put a break on the capital development policy of the majority of the farms ${ }^{8}$. Finally, tightened credit conditions from 2007 led to a deterioration in the financial situation of these holdings. Interviews conducted in 2012 revealed the recent changes in greenhouse production: with external capital (bank credits are necessary to afford the production costs during the season) inaccessible, green pepper cultivation has been partly replaced with other horticultural crops with much lower labour requirements (courgette, melon, broccoli and peas).

\section{Flexibility and adaptation patterns of family farming in the study area}


At this point it is important to consider some distinctive features of this agricultural system in order to develop a better understanding of the particular mindset of farmers in Campo de Cartagena and the organisational practices of farm businesses in this area.

Farms in Campo de Cartagena have been fully exposed to international competitive pressure for decades ${ }^{9}$, a circumstance that has contributed to shape a business-like, risk-taker type of farmer that seeks to take advantage of market opportunities and displays a great capacity for adaptation. Interviewees revealed that crops, varieties and trading seasons adapt rapidly in response to commercial trends; moreover, 81 per cent of the survey farms have joined the Integrated Pest Management Scheme (at least for greenhouse cultivation of green pepper) to respond to the demands of the large European food chains. The profound changes in farm operations that this scheme entails have been undertaken with the support of cooperatives, which provide their members with indispensable technical advice and centralise the delivery of the insects used for the biological pest control. Collective action also helped farmers gain access to other quality labels (EUREPGAP, ISO 9001/2000, etc.) ${ }^{10}$.

Flexible tenancy regimes also play an important role in the adaptable nature of farm management practices. Rented land, typically on a short-term basis (3-5 years), covers 24 per cent of the survey farmland. Greenhouses are commonly located on owned land, but the rental of existing constructions is relatively common in this area, 16 per cent of respondents reporting that they rent at least one construction. Although part of these tenancy agreements can involve members of the same family (see below), interviewees also identify them as a part of the growth strategy of farms. Finally, hired labour constitutes one of the key elements of flexibility in running these farm businesses, acting as a sort of "spring" that adjusts to the changing necessities of the business. Thus, although nearly all the farms of the area $(94$ per cent) occupy at least one member of the family on a full-time basis, two thirds of the Annual Work Units (AWU) are supplied by hired workers, of which 75 per cent are contracted on a temporary basis ${ }^{11}$.

All these considerations shape a farming system in which managerial expertise, technical knowledge and organisational skills are crucial aspects for success ${ }^{12}$. The ability to control the multifaceted aspects of the production process and to enhance the operational efficiency of the farm, together with the means to access external capital, reveal themselves as key elements of farm differentiation. Such elements are sometimes settled in the interplay between the farm and the family, where extended family arrangements of different nature emerge on the borderline between the business rationale and the family forms of production.

\section{Family farm governance structures: categories and rationale}

Around a half of the survey farms (74 out of 135) were reported to have a sole holder, 26 per cent had two and the remaining 19 per cent three or more. Generally, in the latter cases holders do not live in the same household. Although the questionnaire was not specifically designed to generate data for a gender based analysis, the results point to the secondary role that women play with regard to farm ownership. In 91 per cent of the farms with a sole owner, the holder was a man although women participate in farm work (either full or part time) in half of those farms. Significantly, only 13 per cent of farms were jointly held by a couple; two holder partnerships consisting of father-son (or son-in-law) or brother-brother (or brother-inlaw) were as frequent as those involving the two spouses. Women participate more frequently in farm ownership when there are three or more holders (in 20 out of 26 cases).

In order to systematise the analysis of the 'family-scapes' in the study area, three categories of farm families have been identified: 
- 'Monofamily farms', in which both legal ownership and family labour are associated with members of the same household (i.e. those living in the same dwelling). This category also includes farms in which non-resident relatives still play a minor role (eg elder parents helping out in seasonal peaks).

- 'Vertical multifamily farms', in which households with intergenerational kinship take part. To be included in this category, at least one member of each household should be (i) fully employed on the farm, and/or (ii) farm holder by means of a legally formalised partnership.

- 'Horizontal multifamily farms', defined in a similar way to the previous category, but consisting of two or more households linked by a collateral relationship (i.e. siblings) -they may also include the parents' participation and therefore comprise more than one generation.

[Table 2 around here]

The large group of monofamily farms are strongly associated with small-scale holdings, with three quarters occupying only one member of the family on a full-time basis. These data reveal the long stated process of farm individualisation, which has been related to a number of sociological changes within the farm families that resulted in the rupture of family group labour (Blanc, 1987). Recently scholars have stressed the spreading of individual farms in different contexts (eg Nicourt, 2013); our case study shows that this process has reached a significant stage even in an intensive-like farming system which used to employ the labour of the nuclear family in recent times.

More interestingly, in parallel to the individualisation of nucleated family farms, Table 2 points to a considerable presence of holdings held by several households ( 27 per cent of the total, including both 'vertical' and 'horizontal' farms). A few of these businesses uniquely involve a parent and one descendant who continues working on the family farm after leaving home, giving rise to a two-generation holding. The 'vertical multifamily farms' are, thus, equivalent to the "partnership" succession pattern described by Blanc and Perrier-Cornet (1993).

Other farms are reported to be run by several controllers with a collateral kinship connection what we have called 'horizontal multifamily farms'. The survey information has allowed us to construct the family morphology of these arrangements - i.e. the number of households encompassed and their kinship (see Figure 1) -, revealing the degree of complexity achieved by some of them, which in some instances constitute a sort of farm family network. Significantly, no cases of multiple-controller farms were found outside kin relationships ${ }^{13}$. These organisational forms therefore maintain some of their family foundations, but their rationale seems to go much beyond a transitional stage in the process of farm succession.

\section{[Figure 1 around here]}

In-depth interviews conducted with some of these farmers shed light on aspects of the business which benefit from extended family arrangements. The decline of farm labour supplied by the nuclear family may hinder the most aggressive strategies of farm growth, given the difficulty of controlling and supervising the multiple dimensions of farm management by a sole operator. Approaches based on the participation of extended family members make it possible to overcome this fundamental constraint facing the nuclear family business, as Pritchard et al. (2007) indicate in the intensive horticultural farms in Australia. Thus, the great 
majority (78.6 per cent) of the horizontal multifamily farms captured in the survey occupied at least one person on a full-time basis from each nuclear family involved in the business. This organisational form facilitates dividing different aspects of managerial control among family members involved - rather than configuring independent 'farm units' fully controlled by each family. Labour specialisation could provide further advantages in the case of skilled operations (eg computerised irrigation, accounting) or those for which specific training or a license is a legal requirement (eg application of pesticides, food handling) - see Gertler (1999) for a similar argument applied to multiple-operator farms in Canadian prairies.

In addition, farm businesses held by multiple households benefit from a greater capacity for investment by pooling their own financial resources or by facilitating access to bank credit (Marsden, 1984). Indeed, this could be a key determinant of success in the case of green pepper production, due to the high cost of initial set up investment and current costs compared to other vegetables (Gómez-Espín et al. 2011). Survey data on the structural features of horizontal multifamily farms support this assumption: they were found to be larger than other farms - particularly in terms of greenhouse area, which is the determinant of the economic size of the business (see Table 2). Moreover, 50 per cent of horizontal multifamily farms had embarked on the most aggressive strategies of growth (those combining strong intensification and land expansion) in the previous two decades, compared with 30.6 per cent of monofamily farms. At the same time, regressive strategies or stationary situations were relatively less frequent on horizontal multifamily farms ( 7.1 per cent) than on monofamily ones $(17.3 \text { per cent })^{14}$.

Finally, the advantages of extended family partnerships compared to the independent establishment of siblings were also found in terms of economies of scale in certain aspects of farm management. One farmer was clear ${ }^{15}$ in this sense when claiming that "the paperwork is the same for 3 and for 6 hectares, and there is one irrigation pump and filter station for either 3 or 6 hectares". More efficient use is also made of farm equipment such as irrigation infrastructure (eg the pool or the desalinating plant).

Importantly, the 'real' organisational structures do not have to necessarily match with the legal family arrangements. Relatives sometimes operate as a joint technical-economic unit on an informal basis, while keeping a separate status as unincorporated farmers (Figure 1). Sometimes, formal arrangements are used as a way of institutionalising the rights over the land of different family components, either as landowners (when some of them have purchased a part of the farmland on their own account) or as future heirs of family patrimony. One particular case of farm holders interviewed in 2012 (therefore not included in the survey) will help to illustrate this:
Three brothers $A, B$ and $C$ worked alongside their father in the family farm. After their father's demise, as the family farm base was too small to support several families, the eldest brother (A) set up independently on rented land. He worked on the farm together with hired workers and formalised a written partnership with his wife. Later, with the accumulated incomes of the farm business and bank credit, he bought a plantation of citrus trees. $B$ and $C$ continued farming together on the family farm; $B$ dealing with the management of hired workers and $C$ controlling irrigation and transport operations. They gradually enlarged the initial capital base by renting more land for open-air cultivation and already-built greenhouses. B and C have constituted a partnership in which A also takes part; all three pay a small rent to their mother, who retains ownership of the family land.

In exceptional cases, the same 'real' farm is split in two different legal partnerships, following tax advice. Finally, multiple-controller farms can adopt the most convenient (separate or joint) configuration when it comes to other management decisions, such as the membership of a cooperative. A representative of a farmers' union referred to this when he declared that 'they [different family holders] can commercialise separately, but put the money in a pool". In any 
case, multifamily farms were found to be less likely ( 53 per cent) than monofamily farms (72 per cent) to belong to a cooperative, a fact that supports Hervieu and Purseigle's (2011) argument that the "agriculture familiale sociétaire" can eventually have enough of its own capital basis to emancipate from other forms of collective action.

The finding of a significant group of farms exclusively controlled by collaterally-related holders challenges Hutson's (1987) hypothesis that these arrangements are only a transitional stage prior to the division of assets between siblings after the father's retirement, and aligns with Marsden's (1984) observation of a trend in North Humberside in which separate households remained integrated in the family business in the second, and even third generation. In the present case study, the advantages of joint management are important enough to cement family relationships, conferring a stable nature on these highly capitalised businesses under the control of two, three or even four siblings. This is thus a version of family farming situated in the "shadow-zone" (Brookfield and Parsons, 2007: 9) between family and corporate nature, conceptually close - although dissimilar in terms of scale - to what Pritchard et al. (2007) and Magnan (2012) labelled as 'family farm entrepreneurs'.

It is noteworthy that, despite evidence of penetration of market relations in these farms (in terms of use of hired labour, land tenure, incorporation and connection with wider circuits of capital) there are also important elements of "family-ness" in their internal relations, as well as in their genesis and reproduction (see below). In fact, these holdings, as nucleated farms, fulfill most of the criteria used by Gasson and Errington (1993) to define a "family farm business"16. Besides, the interviews revealed that farmers involved in corporate holdings fully perceive themselves as family farmers. According to one interviewee, "people who incorporate do not have different mentality, it is only a different form to declare incomes [for tax purposes], but underneath they keep being family farmers". Another farmer acutely observed: "this is family farming, but we have to articulate it with the mechanisms we have", referring to the financial and legal arrangements. Multifamily farms are acknowledged as the best suited to confront difficult times ("these [farms] are the ones which are holding on", said one farmer), due to the greater commitment with farming when family ties engage the operators. The succession prospects revealed by the 135 farms taking part in the face-to-face survey are in line with the suppositions of the farmers interviewed: whereas 46 per cent of respondents from nucleated family farms expected that they would not have a successor, this proportion was much lower (26 per cent) for multifamily holdings.

\section{Intergenerational farm transfer itineraries}

The survey provides an overall snapshot of the participating farms in 2009; however, as families pass from one stage of the life cycle to another, the interplay between the farm and the family varies in terms of labour, ownership and decision-making (Gasson and Errington, 1993; Potter and Lobley, 1992). The lack of consistent longitudinal data prevents a detailed reconstruction of the 135 family histories. However, some information on the past and expectations of the families captured by the survey questionnaire (eg beginnings in farming, year of formalisation of written agreements, succession prospects), together with the qualitative information from in-depth interviews, allow us to postulate a number of intergenerational farm transfer itineraries - i.e. situations likely to succeed each other with the passage of time.

The boxes displayed in Figure 2 represent different ideal family configurations in relation to the farm business - the number of farms in the sample assignable to each situation being indicated in each box. The arrows depict itineraries joining the different stages or "nodes", more advanced in the family life cycle as we descend in the diagram. The nodes A, B, C, D and F are variants of the category that we have named monofamily farms, whereas $E$ corresponds to 
vertical multifamily farms and different types of horizontal multifamily farms are represented in nodes $\mathrm{G}, \mathrm{H}$ and $\mathrm{I}$.

[Figure 2 around here]

Node A, taken as the starting point, corresponds to a family consisting of a relatively young couple (farm principal below 50 years old), either childless or only with school-age children. Farms in this phase are around the average in the study area in terms of total area and greenhouse area, and show a strong orientation to vegetable production (84 per cent of the farmland on these farms). All the 24 cases found in this situation occupied the farm principal on a full time basis, the wife often being exclusively occupied in childcare (16 cases) or working on the farm on a part-time basis (7 farms). The business principal, who is typically solely responsible for decision-making, remains unincorporated in nearly all cases ( $21 \mathrm{farms}$ ). The individual character of these farms and their intensive orientation result in a prominent role being given to the hired workforce, which accounts for 70 per cent of the total labour input on these farms.

When children reach the end of compulsory education (16 years old in Spain), farms may enter in one of the scenarios depicted in the second level of the scheme. Node B represents the situation where no descendants are working on the farm; as found in previous studies (eg Fennell, 1981; Potter and Lobley, 1996) succession is less assured when the children are not involved in providing farm labour. In fact, very few of these respondents (5 out of 36 cases) foresee the family continuity of the business, with the renting out of land and greenhouse space being the favourite retirement strategy in the case of no succession. In the absence of family continuity (at least in terms of active farming) conservative or even 'regressive' behaviour can be observed as the farmer gets older (eg replacement of greenhouse with open air production, release of rented land, limited investment), thus behaving as 'capital consumers' (Lobley and Potter, 2004). Such adaptive responses may explain the smaller average size $(7.6 \mathrm{Ha})$ and relatively extensive land use exhibited by farms in this node - with a greenhouse surface of only 1.3 ha and notable presence of permanent crops (44 per cent of open air cultivation). Similar strategies of gradual abandonment have been reported in other agricultural systems (eg Ribas et al., 2006). As with Node A, corporate businesses are almost entirely absent in farms of this sort.

In contrast, Nodes $\mathbf{C}$ and $\mathbf{D}$ consist of families with adult children involved in farming, the difference being marked by their degree of autonomy. For instance, in Node $\mathbf{C}$, a son sets up a different farm from his parents" - an equivalent case to the "stand-by holding" described by Blanc and Perrier-Cornet (1993) - even if he is still living in the parental home. However, Node D - where adult children work alongside the father on the 'home farm' - is far more common in this area, arguably because it fits better in a farming system with high demands in terms of labour and managerial control ${ }^{17}$. Aid provided under the Second-Pillar of the CAP for setting-up young farmers is typically utilised at this stage to purchase more land, enlarge greenhouses or modernise irrigation. Expansive strategies result in larger farms (12.8 Ha on average) with the highest proportion of owned land of all nodes ( 87 per cent). Even if successors are frequently involved in farming on a full-time basis (18 out of 23 cases) and sometimes own part of the farmland, at this stage the father is mostly reported to be the only farm holder (17 cases), and corporate businesses are uncommon ( 3 cases). The father is also said to be the main decisionmaker most of the times; however, frequent comments from respondents (such as "my son starts deciding things", "we are making way for the children") point to a gradual transfer of responsibilities to the following generation. In exceptional cases, the successor starts farming 
as paid worker on the home farm before entering into a formal partnership with the father, or before setting up in a separate farm (from Node $\mathbf{D}$ to $\mathbf{C}$ ).

Several organisational forms may follow this once children have left home. When there is only one successor, father and son can continue working together as partners and constitute a vertical multifamily farm (Node E) of a transitional nature. As time passes (Node F) the participation of the parents lessens, taking the form of seasonal help, influence in decisionmaking or, sometimes as an ultimate linkage, tenure arrangements with the successor. Although "fiscal tenancies" largely underlie these situations (as found in other studies, eg Whatmore et al., 1990), they were sometimes found to be truly aimed at compensating the parents' land property rights. Regardless the pattern followed for intergenerational transfer (C, $\mathbf{E}$ or F), the successor's farm will eventually amalgamate with the parents' farm and become again one independent, nuclear farm unit, embodied by the Node $\mathbf{A}$ position.

More complex formulations occur when there are several willing successors involved. Sometimes the initial capital base of the home farm is not sufficient to support several families, and in such cases one successor may set up independently (as in the example explained above $)^{18}$. However, if the initial capital base of the home farm is sufficient to support several families, they can configure a horizontal multifamily farm in which, initially, the parents can still play an important role (Node $\mathbf{G}$ ). In the majority of the cases the two generations are involved both as owners and full-time workers; however, Figure 1 shows that family partnerships sometimes maintain an informal nature at this stage. They are more prone to incorporate when the first generation retires and only collaterally-related holders run the farm (Node $\mathbf{H})$; arguably, the absence of the parents confers a more genuine business nature on these holdings. When written agreements are completed with members of the extended family (spouses frequently take part in them) it is common practice that those who own the land lease it back to the family partnership. As mentioned above, these arrangements can integrate siblings who are not directly involved in farming but hold inheritance rights over the land; however, the great majority of the partnerships found in this node (15 out of 17) were made up by family members who also were fully occupied on the farm, reinforcing the idea of the practical organisational character of these formulations, rather than a merely 'institutional' character.

Our empirical evidence is insufficient to shed light on the transfer of these collateral arrangements to the succeeding generations. The scarcity of farms involving members of the third generation (Node I) could be due to the fact that, according to the survey data, these arrangements were largely formalised in the period of farm expansion following the second half of the 1990s - therefore the following cohort probably was not old enough in 2009 to be party to the agreement. In any case, the analysis of holdings at this stage should consider that the influence of the life cycle in the family's behaviour is made more complex when several households in different stages are involved in the same farm.

Finally, all the surveyed farmers come from farming backgrounds, and the majority entered farming by way of their parents' farm. However, 21 out of 135 respondents reported having started farming as hired workers, subsequently setting up on their own by buying or leasing land or pre-existing greenhouses. All started as independent farmers at Node $\mathbf{A}$ in different periods over the last 35 years, and followed their own itinerary ever since. At the time of the survey, these farm families were present in nearly all the stages represented in the diagram (though more concentrated in Nodes A and B).

\section{Concluding remarks}


This paper has endeavoured to illuminate a largely underexplored research area. The evidence presented here regarding the development of multiple-household arrangements in farming businesses suggests a need for a new research agenda based on an explicit recognition of the variable nature and morphology of family farms. Some of the traditional schemas of family farming literature are found to be insufficient or inappropriate to tackle the analysis of these complex, corporate-style, yet family-based forms of organisation. The overlap between the functional unit of production (the farm) and consumption (the household), commonly accepted in the definitions of family farming (Djurfeldt, 1996), is challenged when multifamily farms are found to be relatively widespread in the field. Despite the full engagement of the extended family in these holdings, the binomial farm-household is also blurred by the significant participation of hired workforce and the importance of non-agricultural incomes to the families involved.

Multifamily arrangements appear to be not mere transitional stages in the intergenerational transfer process, but a stable form of farm governance structure, confirming the findings of Pritchard et al. (2007) and Magnan (2012) in very different contexts. Although there are some gaps in our empirical data (for instance concerning the initial land and capital endowment of the farms), this case study shows that the most vigorous programmes of growth and intensification are associated with multifamily farms - achievements which would prompt a self-reinforcing process of development (Potter and Lobley, 1996). It would seem that the demands imposed by the technological modernisation of agriculture in the case study area and the associated managerial complexity have strengthened, rather than weakened, the family links of these farms. Such relationships have been found to be flexible enough to accommodate external changes and to provide a sound basis for expansion, therefore contributing to the explanation of differential farm development trajectories in the study area.

Given the apparent significance of multifamily farms, it is important to develop a more profound understanding of their internal relations and the power position of different family members - paying much attention to gender roles. In fact, most of the traditional questions of the family farming debate (relating to decision-making, labour organisation, ownership, etc.) may be applied to the analysis of these organisational structures. Importantly however, this would probably require developing methodological tools capable of collecting longitudinal information involving more than one family. Analytical schemes should also be adapted to fully consider these arrangements when it comes to the intergenerational transfer process. In this paper, the limitations imposed by cross-sectional data have led us to define "static", transitional categories (such as "vertical multifamily farms") that have been operationalised using field data. However, there is a need to conceptualise dynamic trajectories capable of capturing different processes of reproduction of family farms. Identifying the conditions under which family members opt to run the farm together instead of setting up separately would provide a valuable basis for a further understanding of farm differentiation at the micro-level. Furthermore, when the agricultural enterprise is only one part of a corporate family enterprise, the unit of analysis to properly tackle business strategy is neither the farm household nor even the multifamily farm, but the "multifamily business portfolio".

From a political economy perspective, in order to avoid over-privileging the agency of the (multi)family, further analysis of internal family relations should be complemented by a broader consideration of the external linkages of these farms. This could also offer an important corrective for the all too easily over-romanticised view of the family farm resisting western capitalism, corporate culture and globalised food networks. The strengthening of extended family links appears to confer a competitive advantage for certain farms, but this is often associated with the simultaneous processes of penetration of capital forces, such as the generalised utilisation of an immigrant workforce (most of the time on a precarious basis) and a dependency on bank borrowing. 
Further, attention should be drawn to the class or dependence relations emerging among farm businesses of a different kind, since extended family partnerships could be the best suited to compete for productive resources - land, water - or exert political influence, putting additional pressure on 'traditional' nucleated farm units. It is also necessary to explore the way in which multiple-household linkages complement, replace or interact with meso-level forms of collective action such as cooperatives or farmers' professional organisations. The role that these holdings play within (formal or informal) inter-farm networks of outsourcing constitutes another interesting research arena (see Moragues-Faus, 2014). Meanwhile, further work is needed to understand the distinctive features and the relative advantages of family-based partnerships such as those that concern us here, and multiple-operator arrangements based on mutual trust. Raymond (2013), for instance, found that non-family partnerships in field crop agriculture were characterised by their easily reversible nature and the non-pooling of assets, which opens the door for interesting comparative lectures.

Finally, the research data on which this paper is based take us beyond the picture of agriculture portrayed by conventional statistics. Much of the agricultural data collected in Europe fails to capture these organisational forms, raising the question of how reliable our current knowledge of farm structures really is. This gap in our knowledge could be significant, particularly if multiple-household arrangements are found to be strongly associated with larger and more dynamic farms operated by risk taking entrepreneurs; then such farms may have an important role to play in a context of increasing concerns over food security (Fish et al. 2013a, 2013b) and economic recovery. Multifamily holdings may be early adopters of new technology and with a degree of business and financial strength may be well placed to compete in global markets. Together these are sufficient reasons to consider multifamily farms as a specific target for agricultural, rural and food policies. Critically however, further research is required on these apparently novel but nevertheless relatively widespread organisational forms in order to understand their social, environmental and economic contributions and how these compare to more conventional forms of family farming.

\section{Acknowledgements}

The authors gratefully thank Eladio Arnalte and the two anonymous referees for their comments to an earlier version of this manuscript.

\section{Notes}

${ }^{1}$ Data from EU refer to the Farm Structure Survey of 2007. In USA, family farms are defined as "those in which the majority of the business is owned by the operator and individuals related to the operator by blood, marriage, or adoption, including relatives that do not live in the operator household".

${ }^{2}$ This work was conducted within the Wye City Group on Statistics on Rural Development and Agriculture Household Income, promoted by the FAO and aimed at exploring comparable methods of data collection across countries. Deliberations on quantitative information available on farm organisational forms have also been made in within the PACIOLI network coordinated from the Agricultural Economics Research Institute of Wageningen. However, these instrumental debates have barely echoed in the scientific literature.

${ }^{3}$ See other works presented at the 94th EAAE Seminar "From households to firms with independent legal status: the spectrum of institutional units in the development of European Agriculture" held in 2005 in Ashford (UK).

${ }^{4}$ A range of studies have shown a positive association between farm size and the likelihood of intergenerational succession (Errington and Tranter, 1991; Gasson et al. 1988, Lobley et al. 2012).

${ }^{5}$ According to the Agricultural Census of 2009 undertaken by the National Institute of Statistics of Spain, the sample accounts for 15 per cent of the farms operating in the three municipalities. 
${ }^{6}$ Following the definition used by EUROSTAT (2014), we understand 'holder' to be the person on whose account and in whose name the farm is operated and who is legally and economically responsible for it. Therefore, the holder coincides with the landowner as long as he/she takes the entrepreneurial risk of the farm; in the cases of land tenure, the holder is the tenant. A farm may have one or several holders, either as natural persons or incorporated by way of a legal agreement.

${ }^{7}$ These data were collected only for the respondent's household.

${ }^{8}$ Moreover, some of the past investments in greenhouses -eg heating, soilless cultivation and thermal shading screens-, were found to be unprofitable due to the excessive costs they entailed, and have been kept inoperative when possible.

${ }^{9}$ Frontier protection has been progressively dismantled by virtue of the successive Euro-Mediterranean Trade Agreements (see García Álvarez-Coque et al., 2010); in the case of green pepper, custom duties charged to Morocco and other competitors were completely eliminated in 2003. In terms of public support, the First-Pillar payments linked to horticulture have never been comparable to the subsidies received by other agricultural products.

${ }^{10}$ Interestingly, the adoption of these quality schemes (even the most restrictive ones such as organic farming, present in 16 per cent of farms) has by no means been incompatible with the productivist rationale prevailing in this agricultural system (Moreno-Pérez, 2013), where exceptional yields are obtained at great pressure on natural resources, particularly water. Because the inter-basin transfer is insufficient to meet the extraordinary demand for irrigation, the overexploitation of aquifers resulting from a great number of irregular wells has brought about a serious salinisation of soils and underground water, a major environmental problem in this zone.

${ }^{11}$ According to the recent interviews with farm holders, immigrant laborers, mainly from Morocco, Equator and Romania, maintain their presence on these farms over the last few years despite the scarce job opportunities for national workers outside agriculture. In this regard, the farmers declared a preference for immigrants compared to Spaniards due to both their acquired experience in specific farm operations and their expected lower exigency in terms of labour conditions.

${ }^{12}$ Although all farming systems require managerial expertise, technical knowledge and organisational skills to varying degrees, greenhouse horticulture is particularly demanding (see Aznar-Sánchez and Galdeano-Gómez, 2011). It is to the lack of these skills, for example, that interviewees attribute the failure over the last years of a small number of newcomers with non-agricultural background that have entered from other sectors of the local economy affected by the crisis.

${ }^{13}$ This aligns with what Barthez (2007) indicates about GAECs (Groupement Agricole d'Exploitation en Commun - Common Farming Groups), an institutional tool created in 1962 in France to give multipleoperator farms a legal status. According to this author, the vast majority of these farm groups are made up of persons maintaining family links.

${ }^{14}$ In a more detailed analysis of the structural dynamics of these farms, Moreno-Pérez et al. (2011) defined 'strong intensification' as the modernisation and/or increase in greenhouse area of the farm, whereas 'regressive' strategies are related with greenhouse downsizing. Stationary situations are those with no substantial changes both in land or capital endowment in the study period.

${ }^{15}$ Quotes have been extracted from the in-depth interviews conducted with farmers and technicians in 2009 and in 2012, not from surveys.

${ }^{16}$ The condition of residence on the farm is not strictly met here; the family usually live in a village close to the farm. This is common in many farming areas in Spain, contrary to the British context that influenced Gasson and Errington's criteria.

${ }^{17}$ Other investigations found the prevalence of this organisational form in contexts of high land prices and strong capitalisation, due to the difficulties for the successor in developing their own capital base (Hastings, 1987; Hutson 1987).

${ }^{18}$ Disassociations of this kind were also common after the daughter's marriage with a farmer or a paid farm worker settled in the zone. A considerable number of respondents reported renting land from their father-in-law. 


\section{References}

Allen, R. and Harris, G. (2005) What we know about the demographics of U.S. farm operators. Agricultural Outlook Forum 2005, USDA

Arnalte, E. (2002) Ajuste estructural y cambios en los modelos productivos de la agricultura española. Pp. 391-426 in C. Gómez-Benito and J.J. González eds., Agricultura y Sociedad en el cambio de siglo (Madrid: McGraw Hill - UNED)

Arnalte-Alegre, E. and Ortiz-Miranda, D. (2013) The 'Southern Model' of European Agriculture Revisited. Pp. 37-74 in D. Ortiz-Miranda, A. Moragues-Faus and E. Arnalte-Alegre eds., Agriculture in Mediterranean Europe: Between Old and New Paradigms. Research in Rural Sociology and Development, 19 (Bingley: Emerald Group Publishing Limited)

Arnalte, E. (2014) Una nota sobre la agricultura familiar y la naturaleza de las unidades productivas en agricultura. Economía Agraria y Recursos Naturales 14 (1). In press

Aznar-Sánchez, J.A. and Galdeano-Gómez, E. (2011) Territory, Cluster and Competitiveness of the Intensive Horticulture in Almería (Spain). The Open Geography Journal 4:103-114

Barthez, A. (2007) Un acte de liberté de pensée en agriculture. La création du GAEC. Économie Rurale 300 pp. 115-119.

Blanc, M. (1987) Family and employment in agriculture; recent changes in France. Journal of Agricultural Economics 38 (2) pp. 289-301

Blanc, M. and Perrier-Cornet, P. (1993) Farm transfer and family entry in the European Community. Sociologia Ruralis 33 (3-4) pp. 319-335

Bollman, R.D. (2005) Family Farms and Farming Families: The Overlap of Two Institutions. $94^{\text {th }}$ EAAE Seminar, Ashford

Brookfield, H. (2008) Family Farms Are Still Around: Time to Invert the Old Agrarian Question. Geography Compass 2/1 pp. 108-126

Brookfield, H. and Parsons, H. (2007) Family Farms: Survival and Prospect. A world-wide analysis (Abingdon and New York: Routledge)

Calus, M. and van Huylenbroeck, G. (2010) The persistence of family farming: a review of explanatory socio-economic and historical factors. Journal of Comparative Family Studies 41 (5) pp. 639-660

Chaplin, H., Davidova, S. and Gorton, M. (2004) Agricultural adjustment and the diversification of farm households and corporate farms in Central Europe. Journal of Rural Studies 20 (1) pp. 61-77

Carney, M. (2005) Corporate Governance and Competitive Advantage in Family-Controlled Firms. Entrepreneurship: Theory and Practice 29(3) pp. 249-265

Clark, N. (2008) Corporate farming in Australia. Rural Market Development. Press Release

Costa, J. and Canales, G. (1980) El cultivo en invernadero y la comercialización agraria en Orihuela y Campo de Cartagena. Cuadernos de Geografía 27 pp. 173-202

Chrisman, J.J., Sharma, P., Steier, L.P. and Chua, J.H. (2013) The influence of family goals, governance, and resources on firm outcomes. Entrepreneurship: Theory and Practice 37 (6) pp. 1249-1261 
Davis, J.E. (1980) Capitalist agricultural development and the exploitation of the propertied laborer. Pp. 133-153 in F.H. Buttel and H. Newby eds. The rural sociology of the advanced societies. (London: Croom Helm)

Djurfeldt, G. (1996) Defining and Operationalizing Family Farming from a Sociological Perspective. Sociologia Ruralis 36 (3) pp. 340-351

Errington, A. (1996) A Comment on Djurfeldt's Definition of Family Farming. Sociologia Ruralis 36 (3) pp. 352-355

Errington, A. and Tranter, R.B. (1991) Getting out of Farming? Part Two: The Farmers. Reading University Farm Management Unit, Study No. 27

European Commission (2012) Agriculture in the European Union. Statistical and economic Information. Report 2012

EUROSTAT (2014) Agriculture Glossary. http://epp.eurostat.ec.europa.eu/statistics_explained/index.php/Glossary:Holder_of_agricultu ral_holding (accessed 04.03.2014)

Evans, N. (2009) Adjustment strategies revisited: agricultural change in the Welsh Marches. Journal of Rural Studies 25 (2) pp. 127-230

Fennell, R. (1981) Farm succession in the European Community. Sociologia Ruralis 21 (1) pp. $19-42$

Fish, R., Winter, M. and Lobley, M. (2013) Food security and an ecosystems approach: a framework for the sustainable intensification of agriculture? Policy Sciences DOI: 10.1007/s11077-013-9183-0

Fish, R., Lobley, M. and Winter, M. (2013) A license to produce? Farmer interpretations of the new food security agenda. Journal of Rural Studies 29 (1) pp. 40-49

Friedmann, H. (1978) World market, state and family farm: social bases of household production in the era of wage labour. Comparative Studies in Society in History 20 (4) pp. 545586

Galdeano-Gómez, E., Aznar-Sánchez, J.A. and Pérez-Mesa, J.C. (2011) The Complexity of Theories on Rural Development in Europe: An Analysis of the Paradigmatic Case of Almería (South-east Spain). Sociologia Ruralis 51 (1) pp. 54-78

García Álvarez-Coque, J.M., Martínez-Gómez, V. and Villanueva, M. (2010) Seasonal protection of F\&V imports in the EU: impacts of the entry price system. Agricultural Economics 41 (2) pp. 205-218

Gasson, R. and Errington, A. (1993) The Farm Family Business (Wallingford: CAB International)

Gasson, R. Crow, G., Errington, A., Hutson, J., Marsden, T. et al. (1988) The Farm as a Family Business: A Review. Journal of Agricultural Economics 39 (1) pp. 1-41

Gertler, M. (1999) Sustainable Communities and Sustainable Agriculture on the Prairies. Pp. 121-139 in J. Pierce and A. Dale, eds. Communities, Development, and Sustainability Across Canada (Vancouver: UBC Press)

Gómez-Espín, J.M., López-Fernández, J.A. and Montaner-Salas, M.E. (Coord) (2011) Modernización de regadíos: Sostenibilidad social y económica. La singularidad de los regadíos en el Trasvase Tajo-Segura (Murcia: Universidad de Murcia)

Irava, W. J. and Moores, K. (2010) Clarifying the strategic advantage of familiness: Unbundling its dimensions and highlighting its paradoxes. Journal of Family Business Strategy 1 (3) pp. 131144 
Hastings, M. (1987) Farming wives as business managers. Farm Management 6 (8) pp. 309-315 Hervieu, B. and Purseigle, F. (2011) Des agricultures avec des agriculteurs. Une nécessité pour l'Europe. Projet 321 pp. 60-69

Hervieu, B. and Purseigle, F. (2013) Sociologie des mondes agricoles (Paris: Armand Colin)

Hill, B. (1993) The 'Myth' of the Family Farm: Defining the Family Farm and Assessing its Importance in the European Community. Journal of Rural Studies 9 (4) pp. 359-370

Hill, B. (2006) Structural Change in European Agriculture. Pp. 5-21 in D. Blandford and B. Hill eds, Policy Reform and Adjustment in the Agricultural Sectors of Developed Countries (Wallingford: CAB International)

Hoppe, R.A. and Banker, D.E. (2010) Structure and Finances of U.S. Farms. Family Farm Report, 2010 Edition. Economic Research Service, USDA

Hoppe, R., Korb, P. and Banker, D. (2008) Million-Dollar Farms in the New Century. Economic Information Bulletin No. 42. USDA, Economic Research Service

Hutson, J. (1987) Fathers and sons: family farms, family businesses and the farming industry. Sociology 21(2) pp. 215-29

Ilbery, B. and Bowler, I. (1998) From agricultural productivism to post-productivism. Pp 57-84 in B. Ilbery ed, The geography of rural change (Harlow: Pearson)

Kinsella, J., Wilson, S. de Jong, F and Renting, H. (2000) Pluriactivity as a livelihood strategy in Irish farm households and its role in rural development. Sociologia Ruralis 40 (4) pp. 481-496

Johnsen, S. (2004) The redefinition of family farming: agricultural restructuring and farm adjustment in Waihemo, New Zeland. Journal of Rural Studies 20 (4) pp. 419-432

Johnson, J., Morehart, M., Poppe, K., Culver, D. and Salvioni, C. (2009) Ownership, Governance, and the Measurement of Income for Farms and Farm Households: Evidence from National Surveys. Statistics on Rural Development and Agriculture Household Income. Pp. 21-46 in Proceedings of the II Meeting of the Wye City Group (Rome: FAO)

Lillywhite, J.M. and Duffy, M. (2001) Multifamily farms and America's farm structure: A new perspective on an old issue. American Journal of Alternative Agriculture 16 (4) pp. 184-190

Lobley, M. and Potter, C. (2004) Agricultural change and restructuring: recent evidence from a survey of agricultural households in England. Journal of Rural Studies 20 (4) pp. 499-510

Lobley, M., Baker, J.R. and Whitehead, I. (2012) Keeping it in the Family. International Perspectives on Succession and Retirement on Family Farms (Aldershot: Ashgate)

Machum, S. (2005) The Persistence of Family Farming in the Wake of Agribusiness: A New Brunswick, Canada Case Study. Journal of Comparative Family Studies 36 (3) pp. 377-390

Magnan, A. (2012) New avenues of farm corporatization in the prairie grains sector: farm family entrepreneurs and the case of One Earth Farms. Agriculture and Human Values 29 (2) pp. 161-175

Marsden, T. Banks, J. and Bristow, G. (2002) The social management of rural nature: understanding agrarian based rural development. Environment and Planning A 34 (5) pp. 809825

Marsden, T., Munton, R.,Whatmore, S. and Little, J. (1989) Strategies for coping in capitalist agriculture: an examination of the responses of farm families in British agriculture. Geoforum 20 (1) pp. 1-14 
Marsden, T., Munton, R. and Ward, N. (1992) Incorporating social trajectories into uneven agrarian development: Farm businesses in Upland and Lowland Britain. Sociologia Ruralis 32 (4) pp. $408-430$

Marsden,T. (1984) Capitalist farming and the farm family: A case study. Sociology 18 (2) pp. 205-224

Mazzi, C. (2011) Family business and financial performance: Current state of knowledge and future research challenges. Journal of Family Business Strategy 2 (3) pp. 166-181.

McNally, S. (2001) Farm diversification in England and Wales - what can we learn from the farm business survey? Journal of Rural Studies 17 (2) pp. 247-257

Meert, H., Van Huylenbroeck, G., Vernimmen, T., Bourgeois, M. and van Hecke, E. (2005) Farm household survival strategies and diversification on marginal farms. Journal of Rural Studies 21 pp. 81-97

Moragues-Faus, A. (2014) How is agriculture reproduced? Unfolding farmers' interdependencies in small-scale Mediterranean olive oil production. Journal of Rural Studies 34 pp. $139-151$

Morales Gil, A. (1997) Aspectos geográficos de la horticultura de ciclo manipulado en España. Universidad de Alicante, Spain

Moreno-Pérez, O., Arnalte-Alegre, E. and Ortiz-Miranda, D. (2011) Breaking down the growth of family farms: A case study of an intensive Mediterranean Agriculture. Agricultural Systems 104 (6) pp. 500-511

Moreno-Pérez, O. (2013) Reproducing Productivism in Spanish Agricultural Systems. Pp. 121147 in D. Ortiz-Miranda, A. Moragues-Faus and E. Arnalte-Alegre eds, Agriculture in Mediterranean Europe: Between Old and New Paradigms. Research in Rural Sociology and Development, 19 (Bingley: Emerald Group Publishing Limited)

Moreno-Pérez, O. and Ortiz-Miranda, D. (2008) Understanding structural adjustment in Spanish arable crop farms: policies, technology and multifunctionality. Spanish Journal of Agricultural Research 6 (2) pp. 153-165

Munton, R. and Marsden, T. (1991) Dualism or Diversity in Family Farming. Geoforum 22(1) pp. 105-117

Nguyen, G. and Purseigle, F. (2012) The emergence of "firm" agriculture in France: Characteristics and coexistence with family farms. IFSA Symposium, Workshop 1.3. Available in http://www.worldagricultureswatch.org/sites/default/files/documents/s3 4 nguyen purseigl e.pdf (accessed 11.03.2014)

Nicourt, C. (2013) Etre agriculteur aujourd'hui. L'individualisation du travail des agriculteurs. (Paris: Quae)

Pedreño, A. (1999) Del Jornalero Agrícola al Obrero de las Factorías Vegetales (Madrid: Ministerio de Agricultura, Pesca y Alimentación)

Poppe, K., van der Veen, H., van Bommel, K. and van Everdingen, W. (2004) Developments in the organisation of the farm and their policy implications. Coloquio de la Societé Fraçaise $d^{\prime}$ Economie Rurale. Paris

Potter, C. and Lobley, M. (1992) Ageing and Succession on Family Farms: The Impact on Decision-making and Land Use. Sociologia Ruralis 32 (2/3) pp. 317-334

Potter, C. and Lobley, M. (1996) Unbroken Threads? Succession and its Effects on Family Farms in Britain. Sociologia Ruralis 36 (3) pp. 286-306 
Pritchard, B., Burch, D. and Lawrence, G. (2007) Neither 'family' nor 'corporate' farming: Australian tomato growers as family farm entrepreneurs. Journal of Rural Studies 23 (1) pp. 7587

Raymond, A.B. de (2013) Detaching from agriculture? Field-crop specialization as a challenge to family farming in northern Côte d'Or, France. Journal of Rural Studies 32 pp. 283-294.

Ribas, A., López-Iglesias, E., Loureiro, M.L. (2006) Los factores determinantes del peso de las explotaciones de leche a carne en la Cornisa Cantábrica: Análisis empírico para una comarca del interior de Galicia. Economía Agraria y Recursos Naturales 6 (11) pp. 139-156

Schmitt, G. (1991) Why is the agriculture of advanced Western economies still organised by family farms? Will this continue to be so in the future? European Review of Agricultural Economics 18 (3-4) pp. 443-458

USDA (2009) 2007 Census of Agriculture. United States Summary and State Data. National Agricultural Statistics Service

Van der Ploeg, J.D. and Roep, D. (2003) Multifunctionality and rural development: the actual situation in Europe. Pp. 37-53 in G. Durand and G. van Huylenbroeck eds. Multifunctional Agriculture. A New Paradigm for European Agriculture and Rural Development. (Hampshire: Ashgate)

Van der Veen, H. and van Bommel, K. (2005) Structure and Strategy, How Do They Match in the Netherlands? 94th EAAE Seminar, Ashford.

Whatmore, S., Munton, R., Little, J. and Marsden, T. (1987) Towards a typology of farm businesses in contemporary British agriculture. Sociologia Ruralis 27 (1) pp. 21-37

Whatmore, S., Munton, R. and Marsden, T. (1990) The Rural Restructuring Process: Emerging Divisions of Agricultural Property Rights. Regional Studies 24 (3) pp. 235-245 
Table 1. Main structural changes in farms, 1990-2009

\begin{tabular}{lcc}
\hline & Number of farms & Percentage \\
\hline Increase in greenhouse surface & 102 & $75.6 \%$ \\
Maintenance of greenhouse surface* & 24 & $17.8 \%$ \\
Decrease in greenhouse surface & 9 & $6.7 \%$ \\
Refurbishment of greenhouses & 61 & $45.2 \%$ \\
Land purchase & 32 & $23.7 \%$ \\
Increase in rented land & 21 & $15.6 \%$ \\
Release of farmland & 7 & $5.2 \%$ \\
Modernisation of irrigation & 61 & $45.3 \%$ \\
\hline
\end{tabular}

* Or absence of greenhouse throughout all the period.

Source: Authors' Farm Survey

Table 2. Farm labour and structure per category

\begin{tabular}{lcccc}
\hline & $\begin{array}{c}\text { Monofamily } \\
\text { farms }\end{array}$ & $\begin{array}{c}\text { Vertical } \\
\text { multifamily } \\
\text { farms }\end{array}$ & $\begin{array}{c}\text { Horizontal } \\
\text { multifamily } \\
\text { farms }\end{array}$ & All farms \\
\hline Number of holdings & 98 & 9 & 28 & 135 \\
Percentage & $72.6 \%$ & $6.7 \%$ & $20.7 \%$ & $100.0 \%$ \\
$\begin{array}{l}\text { Average farmland (hectares) } \\
\text { Average greenhouse surface }\end{array}$ & 8.8 & 10.8 & 11.32 & 9.5 \\
$\begin{array}{l}\text { (hectares) } \\
\text { Nuclear family labour }\end{array}$ & 2.0 & 2.0 & 4.9 & 2.9 \\
$\begin{array}{l}\text { (Average AWU) } \\
\text { Extended family labour }\end{array}$ & 1.35 & 1.17 & 1.10 & 1.29 \\
$\begin{array}{l}\text { (Average AWU) } \\
\text { Hired labour (Average AWU) }\end{array}$ & 0.03 & 0.80 & 1.46 & 0.38 \\
\hline
\end{tabular}

Source: Authors' Farm Survey 
Figure 1. The relationship between family and legal organisational forms in horizontal multifamily farms

\begin{tabular}{|c|c|c|}
\hline “Family morphology" & $\frac{\text { Number of farms in }}{\text { the sample }}$ & Legal arrangements \\
\hline $\begin{array}{l}\text { Parents - two adult } \\
\text { children }\end{array}$ & 7 & $\begin{array}{l}5 \text { informal arrangements; } 2 \\
\text { cases were legally formalised }\end{array}$ \\
\hline Two siblings & 10 & Legally formalised in 9 cases \\
\hline Three siblings & 6 & Legally formalised in 4 cases \\
\hline Four siblings & 1 & Legally formalised \\
\hline $\begin{array}{l}\text { Parents-three adult } \\
\text { children }\end{array}$ & 1 & Split in two legal partnerships \\
\hline $\begin{array}{l}\text { Parents-four adult } \\
\text { children }\end{array}$ & 1 & Legally formalised \\
\hline Three siblings-one son & 1 & Legally formalised \\
\hline $\begin{array}{l}\text { Father-four siblings-one } \\
\text { son }\end{array}$ & 1 & Legally formalised \\
\hline
\end{tabular}

Note: White circles represent a household belonging to the first generation; black circles correspond to the second generation, grey circles represent the third generation.

Source: Own elaboration. 